\title{
Where humanism finds its ends: Lessons from Pia Arke and Katarina Pirak Sikku on the difficulty of narrating the Arctic
}

\author{
Stefan Jonsson
}

Journal Article

\section{Tweet}

N.B.: When citing this work, cite the original article.

This is an electronic version of an article published in:

Stefan Jonsson , Where humanism finds its ends: Lessons from Pia Arke and Katarina Pirak Sikku on the difficulty of narrating the Arctic, Studies in Travel Writing, 2016. 20(3), pp.1-11. Studies in Travel Writing is available online at informaworldTM:

http://dx.doi.org/10.1080/13645145.2016.1212502

Copyright: Taylor \& Francis (Routledge): SSH Titles

http://www.routledge.com/

Preprint available at: Linköping University Electronic Press

http://urn.kb.se/resolve?urn=urn:nbn:se:liu:diva-131553

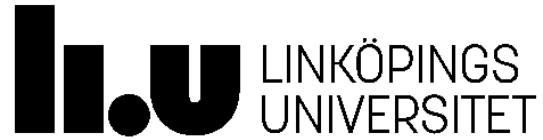




\section{Where Humanism Finds its Ends: Lessons from Pia Arke and Katarina Pirak Sikku on the Difficulty of Narrating the Arctic}

Stefan Jonsson

\section{ABSTRACT}

This article argues that any attempt to conceive of a new narrative of the Postcolonial Arctic will fail, if it does not also entail a new narrative of European history. It starts out by asserting the strong afterlife of colonial narratives of the Arctic, through the example of the author's own difficulty of writing an authentic and ethically acceptable reportage about East Greenland. By drawing on further examples and by introducing narratological theory, the article moves on to consider the colonial narrative of the arctic. It is asserted that the prototypical colonial narrative of the Arctic may be modelled on Moby Dick: a hunting and whaling story, in which the setting is made up landscape, wildlife, and indigenous populations. The colonial narrative is gradually transformed as the indigenous peoples of the Arctic leaves the setting and becomes agents in the narrative. Indeed, it is only when the indigenous attains the place of the subject telling the story that we can seriously claim to have a postcolonial narrative of the Arctic. The article then briefly analyses two instances of such transformations of the colonial narrative: the works of Danish-Greenlandic visual artist and artistic researcher Pia Arke, and of the Sami visual artist Katarina Pirka Sikku. Both question the narrating subject in travel literature and scientific discourse about the Arctic. They reclaim that position for themselves, which results in narrative and visual performances of a immense interest. 
Keywords: colonialism, postcolonial, Arctic region, colonial narrative, Pia Arke, Katarina Pirak Sikku, Sami culture and aesthetics, Inuit culture, Indigenous movements in art, culture, literature, narratology

\section{Blackout}

I first visited Greenland in $1998 .{ }^{1}$ I did not go to its most accessible part, but to the still fairly remote settlement of Ittoqqortoormiit, or Scoresbysund, on the east coast. I went there to meet up with my friend Pia Arke. We were going to work together on a book project: what later became Stories from Scoresbysund: Photography, Colonization and Cartography (Arke 2003). ${ }^{2}$ Pia had persuaded me to collaborate with her on the history of the colonial settlement of Scoresbysund and the memories of it that survive today. She was going to record this history “from below” by interviewing the villagers and collecting their images, stories, and testimonials. Many of them were her relatives; she herself was born there in 1958. My role was to write a critical history of the colonization process by showing how Scoresbysund and East Greenland became objects of cartography: were gradually put onto the map.

The book project (about which more shortly) was my real reason for going to East Greenland. Yet in order to finance my trip - or expedition, if we adhere to standard vocabulary in narratives of the Arctic region - I had had to invent a secondary but official purpose. Since I was working at the time as a cultural critic at Dagens Nyheter, Sweden’s major newspaper, I had managed to get it to pay for the expensive tickets. In return, I was expected to write a substantial piece of reportage, a narrative of the Arctic.

The route took me from Stockholm to Reykjavik, then on to the airstrip at the meteorological station at Constable’s Point, where passengers from Reykjavik were transported to Ittoqqortoormiit by helicopter in groups of five or six. The other travellers were 
secondary school students returning home for their summer holidays from boarding school in Nuuk, West Greenland, and they had no other route to take than the one via the Icelandic capital. At the helicopter landing site they were greeted by cheerful parents and siblings. Pia and her son Sören were there to welcome me; they had arrived in Ittoqqortoormiit a couple of weeks earlier. We immediately set to work on our project, since we only had a few days in Ittoqqortoormiit before Pia would go back to Copenhagen. I would remain to collect material for our book, and for the journalistic narrative that I also had to do.

While the first task was easy, interesting, and pleasant, the journalistic enterprise turned out to be exasperating. The writing of a report about Ittoqqortoormiit, and the Arctic more generally, for the general Scandinavian public presented nearly insurmountable difficulties, especially so for a person like me, a critically minded European intellectual with substantial knowledge of Denmark's and Europe’s colonial past and its postcolonial critique. Unlike other writers and reporters who had visited the place before, I could not write about the midnight sun; nor about the thawing ice on the bay where the villagers were walking, playing, or fishing; nor about the sealskins and the more rare polar-bear skins that were suspended in frames on the porches of many of the houses; nor about the huskies digging into the snow just outside my window. And it was equally impossible to write about the villagers, because they kept to themselves. As for the Danes - the police officer, the medical doctor, the nurse, the engineer, the municipal director and the trader made up a small colonial elite in the village - I was not much interested in their views. Rather, I was groping for some more authentic and revealing narrative about the place I was visiting - or so I thought.

But I also could not write straightforwardly about present-day Ittoqqortoormiit - its widespread social misery, domestic violence, and alcoholism; its apparently hopeless economic prospect; its dependence on money transfers from Nuuk and Copenhagen; or its continuous history of economic hardship and looming collapse (the Danish project, which in 
1925 established an Inuit settlement that was supposed to sustain itself on hunting and fishing, had been unrealistic from the outset). This narrative of social disintegration had already been told by many returning Danes, the worst coming from a doctor who had argued that the village should simply be closed down and its inhabitants forced to relocate.

Yet in confessing that I could not write about any of this, I of course mean the opposite. The fact is that I could easily have written about all of this, just as many visitors had done before me. Indeed, this is precisely what would have been expected and rewarded back home in Stockholm. But it would have been too easy, too disrespectful of the people of Ittoqqortoormiit. And above all, it would have been false.

Let me put this differently. People like me, white Europeans, sons and daughters of a culture which not long ago admired explorers, conquerors, colonizers, miners and landgrabbers, and who in many cases continue to do so, people like us are pre-conditioned to narrate the Arctic by relying on a very limited set of generic modalities. This is what dawned on me in Ittoqqortoormiit: the extent to which I was invaded as much as informed by a preexisting storyline that twisted my imagination each time I tried to put my thoughts into words and to make sense of my experience. As a writer, I have never felt as incapable as I did during those weeks in Ittoqqortoormiit. I had to say something about the place, had to produce a narrative, yet could not do it without falling prey to clichés of the worst kind. What I wanted to tell in my report, I could not narrate. And what I could narrate, I did not want to tell, for it would have amounted to just another colonial narrative, just another story about the male subject of modernity conquering nature, speaking for others and placing himself at the centre of the universe; just another case of western humanism, or rather a caricature of humanism, corrupted and deranged. What I was capable of producing was just that, and no more than that. So I fell silent. I did not have access to any "new narratives” of the Arctic, and the old ones were all debauched by a long and violent history of colonial and neocolonial travel 
writing, dubious ethnography, and adventure literature. Later, I did gain access, but only by learning from the work of Pia Arke (see Jonsson 2005, 516-529); I shall examine that lesson presently. The rest of my days in Ittoqqortoormiit I spent reading and taking walks.

But this option of silence was of course a cliché in turn: the white male European travel writer visiting the periphery to learn something new only to be overcome, if not by colonial guilt, then at least by an exaggerated self-reflexivity, a paralyzing alienation both from his habitual self and from strangers with whom he is unable to communicate. It was the experience of a civilizational blackout.

\section{The Colonial Arctic}

In one sense just a personal anecdote, this opening offers a glimpse of an attitude that should be read as a symptom. For what I experienced in Ittoqqortoormiit was an effect of how the history of colonialism - in the broad sense of the term - has positioned European travelers and writers in a geo-cultural force field that limits their access to the Arctic, predetermining the narratives that will emerge from that encounter. In general terms, my example illustrates two standard versions of a colonial narrative of the Arctic. In the first version of this narrative, the narrating subject reproduces the system by manufacturing yet another tale of igloos and Eskimos. In the second, the subject questions himself and his place, his voice, and his agency, yet can find no alternative way of telling and is ultimately condemned to saying nothing at all.

But here we can take another step in realizing that these two versions of the colonial narrative of the Arctic correspond closely to the ends of humanism that I have evoked in the title of my chapter: "Where Humanism Finds its Ends”. In the first version, the purpose of humanism consists in its situating of the human subject at the centre of the world, planting the flag, proclaiming that this all belongs to the master. In the second, we encounter the end of humanism in the opposite sense, for here the humanist tradition runs up against its limits, 
either buckling under pressure from alien surroundings and experiencing its own impotence and vulnerability, or being literally wiped out. To put this differently, we are given the message - whether concretely through Greenland's melting glaciers, or more abstractly through some general recognition that the western notion of the human no longer occupies the centre of the world around which everything else gravitates - that we have entered the Anthropocene, which is also according to many theorists the era of posthumanism. These are the alternative ends of humanism as we can perceive them in colonial narratives of the Arctic: either the absolute power of a certain western conception of the human or, on the contrary, the absolute powerlessness and insignificance of the human. And if humanism finds its ends in the colonial narrative of the Arctic, this also means that this narrative displays humanism from both ends, as at once the apotheosis of human capacity and its annihilation.

So much for the colonial narrative of the Arctic; what then might one say about the question concerning a new postcolonial narrative of the Arctic, one supposedly equipped to address this posthumanist condition? But I will postpone that argument for now, because before we even try to address the question of Arctic postcoloniality we must make clear that the dominant narrative of the Arctic today is still the colonial one. It persists strongly in virtually all accounts produced about the Arctic in Europe (for analyses of this see, for example, MacKenzie and Westerstahl; Stenport et al. 2014; Bravo and Sörlin 2002; Ryall, Schimanski and Howlid Wærp 2010). In international relations, tourism, and mainstream media coverage, to mention just three prominent examples, the Arctic is still largely a colonial space, at best a place of colonial struggle, at worst little more than a natural resource deposit to be extracted by transnational capitalism. It is therefore important to avoid mistaking the postcolonial for something that arrives after the colonial. We should instead see the postcolonial as an attitude, discourse, and practice that emerge as a critique of colonialism and its persistent epistemological and political legacies. This is a simple point, and one that 
has been made often enough, but in the case of the Arctic it becomes more urgent than ever because the Arctic region is one of the areas of the world where we still encounter an active and expanding colonial frontier (Stuhl 2013). (The Amazon would be the other great example.)

These introductory remarks amount to a first hypothesis. Any reliable and trustworthy travel narrative of the Arctic today must position itself at the aforementioned junction where residual yet still dominant colonial narratives fail to convey emerging postcolonial realities, and where the humanist tradition effectively reaches its end, passing over into various posthumanist projections and imaginings. It is from this position that I will now go on to explore what narratives can be told, and by whom, focusing on the works of Pia Arke and the Swedish-Sami artist Katarina Pirak Sikku.

\section{Whaling Stories}

A narrative of igloos and Eskimos, told by a human subject who arrives from the centre of the world to claim ownership of the periphery on behalf of a modernity that conquers nature and maps the periphery: if this is the paradigmatic colonial narrative, we immediately realize that, in its most simple form, it amounts to a hunting and whaling story. A man (it is nearly always a man) goes out, kills the animal, and brings it home. Alternatively, the man is killed by the animal or by other forces of nature. In short, the colonial narrative in prototypical form is Herman Melville’s Moby-Dick (1851). The hero may of course also be an artist, a writer, a photographer, an explorer or a scientist, but the form remains the same: he goes out, pursues his object, and brings it back as a collector's item, to be displayed vaingloriously to the public back home. Whether he comes back alive (like Roald Amundsen) or dead (like Robert Scott) matters less. In both cases, the protagonist is celebrated as a hero of civilization. In both cases, he essentially remains a hunter. 
Interestingly, what I have said about the colonial narrative is also a basic description of any narrative, or tale, according to classical narratology, which has argued that most simple stories are so-called quest narratives: departure - pursuit - achievement - heroic return; or: departure - pursuit - failure - heroic death (Greimas 1966). To this elementary logic is added what Vladimir Propp (1928), the founder of narratology, termed “helpers” (or “donors”) and “aggressors” (or “villains”), i.e. the subject pursues an object, is blocked by “aggressors” and assisted by "helpers", after which he finally attains the object and returns, if he is not killed (see also Jameson 1974).

In addition to these basic narrative agents or actants, much of the typical fabric of narratives of the Arctic consists of setting: ice, rock, wildlife, water, weather and austere scenery in endless variations and combinational forms. Now, one of the characteristic features of the colonial narrative of the Arctic, inherited from Moby-Dick, is that nature itself becomes an agent in the story, often to the extent that the pursuit of the object (the hunting and killing of the animal, etc.) becomes a pretext for telling a narrative about man's struggle against the elements. This is often a struggle to the death, hence the grisly appeal of such narratives in the western metropoles: a select representative of our civilization - whether he is called Roald Amundsen, Fridtjof Nansen, Knud Rasmussen, Ejnar Mikkelsen, Umberto Nobile, Salomon August André, Robert Scott, or Lauge Koch - is willing to risk his life and sacrifice himself in order to extend and symbolically demonstrate the power of our civilization over nature and “nothingness”. In its most rudimentary form, this scenario depicts a struggle between human beings and the natural world, the former being identified with civilization and Europe, the latter with the Arctic.

In this context, the essential question is what happens when the Arctic is inserted into the plot, not as nature writ large but as a particular social and human world. When indigenous people are first allowed to enter into prototypically colonial narratives of the Arctic, they tend 
predictably to do so as part of the setting through which the white male explorer or hunter moves. In a second step, distinctions appear among these people, some of them coming forward as "helpers" while others are condemned as "villains", although the vast majority of them are still confined within said setting along with other standard commodities of Arctic nature such as polar bears, icebergs, mountain ranges, sledges and huts. The history of the colonization of Scoresbysund is a good example of this process. In 1924 and 1925, some twenty families from Amassalik were enlisted as "helpers” in the Danish effort to populate northeast Greenland in order to support its push for territorial sovereignty against Norway, which at the time was making similar claims (Arke 2003/2010).

In a third, more radical step, indigenous people become the very object of Arctic narrative. It is not until this stage that we can speak of the colonial narrative of the Arctic as being a narrative about the "civilizing mission" in its strictest sense. The task at this stage is, rather, to measure, collect, discipline, and govern indigenous people themselves - and for their own benefit. In order to understand what this process involves, it is useful to look the artistic works of Pia Arke and Katarina Pirak Sikku, which reveal in their respective aesthetic mannerisms and gestures just what the objectification of the Arctic entails. These works also enact a transformation whereby the standard object of the colonial narrative wrests itself from its position of subordination and places itself as the subject of a new discourse, a new critical narrative. The extent to which we can call this a "postcolonial” narrative remains to be seen, as I will now explore below.

\section{Postcolonial Performance}

At the height of colonialism and racism, Inuit women were physically abused and put on display by white explorers, physicians, and anthropologists. Some of these women were diagnosed with a mental disorder termed “Arctic hysteria”. Scientific and scholarly careers 
were made on the backs of these women, as medical researchers sought to have this newly discovered psychopathology classified and inserted into the handbooks of psychiatry. Victims of western culture, the women so diagnosed were treated by that culture as belonging to a wild species of nature. In a portfolio of works entitled “Arctic hysteria”, Pia Arke brings these women out of the dark, forcing upon the viewer and reader an act of remembrance and recognition (Tupilakosaurus Guide 2010, 23).

Arke traced these women in old ethnographic documents and collections, and she also reexhibited them, but now beside their masters and more or less as their equals. We might well envisage her as stretching out as far as she could toward the periphery, as if she wanted to give voice to her poor sisters, to represent them and reclaim for them the human status of which they had been deprived. But what she was actually revealing is that what we find at the periphery of world history is neither wilderness nor insanity, but a mirror image of western colonialism. What were once perceived to be representations of natives in a state of savagery would in Arke's work turn out to be projections of the colonizer’s own irrational violence.

Arke’s purpose was to indicate the limits of what can be included as an object in the colonial narrative of the Arctic. That limit is marked by brutalized women. Here as elsewhere, these women are not just women in general, but brown-skinned females: materially and mentally violated; subjected to objectification, description, representation and normalization. Cultural theory has yet to produce a concept able to inscribe female figures like these into the world historical text, or to explain why they appear so frequently in the colonial narrative as border markers of the unknown and the dangerous. It is one of the achievements of Arke's work to have served as a powerful reminder of this omission and blindness. We have no concept at hand to represent this figure as an agent in the Arctic narrative; most often, colonial narratives of the Arctic posit her as the pure object of colonial desire and violence. But if we turn these narratives around, we can also see that she functions as a utopian 
"horizon figure"; and her gestures allow us to glimpse wholly different ways of organizing and narrating the world, ways which potentially shed light on what post- or decolonial practices entail (Jonsson 2014). For if a post- or decolonial narrative of the Arctic can be envisioned, it needs to take figures like these as subjects - as points of departure, less for a narrative representation than a narrative performance. Many of Arke’s works may be seen as powerful performances, or even entire dramas, enacted so as to oppose a dominant regime of representation. Sometimes, this is literally the case, as in a performance piece entitled "Arctic Hysteria”, where Arke filmed herself naked and crawling like an animal on a huge enlargement of her photo of a Greenlandic landscape, smelling and scratching the surface as though she wanted to enter into the picture and disappear into the ice-and-snow-covered landscape. The performance ends with her tearing the photograph to pieces. Several of Arke’s works involve dramas of this kind, in which material products of the colonial order are physically destroyed or recycled in unimaginable ways (see, for example, Legend and Tupilakosaurus). Such artworks should not just be called counter-representations or counternarratives. Rather, they are carefully prepared and meticulously documented performances that shake so hard at the foundations of the colonial master and the exhibited native that neither of them will ever regain their previous positions. What we are looking for, then, in our search for a postcolonial symbolization of the Arctic is perhaps not so much a narrative of the Arctic as its performance.

\section{Sami Resistance}

In Katarina Pirak Sikku's oeuvre, likewise, the object of the colonial narrative is turned into the subject of a different, postcolonial story. Pirak Sikku has devoted her artistic career to representations and performances that ask what it is like to be transformed into a scientific 
specimen; to be treated as an object or insect; to be captured, recorded, measured, classified and inserted into a scientific table or diagram.

In 1913, the Swedish scientist Herman Lundborg embarked on an "official survey" of the “Lappish race” in northern Sweden. His work was generously funded by the Swedish parliament. Fieldwork included anthropometry, photographical documentation, and bloodgroup identification of all members of the Sami population. In 1922, this work became the flagship project of a newly founded State institute of Race Biology. This history provides both background and material for Pirak Sikku's work, which engages the audience in an act of identification and historical reflection. It is an act of identification in the sense that it asks what it was like to be ordered to undress and stand in front of the camera; to have your measures taken and be recorded as a set of numerical data in statistical surveys and photographic atlases, and all this as an example of an "inferior" and "dying” race. And it is also an act of historical reflection in the sense that it asks urgent questions about the Swedish politics and society that for a long period supported a science whose objective it was to represent the Samís as a supposedly "lesser” race in the process of "dying out”. Who was the subject of this story? And in whose interests was this done: those of science, or those of the Swedish State, or those perhaps of the Swedish people?

While such questions are central to any effort to come to terms with colonial history and redress the suffering of its victims, Katarina Pirak Sikku’s project also poses a third, predominantly aesthetic, problem: how can she herself, as a descendant of a people once slated for extinction, approach this history and turn it into her own story, adapting it in the process to her own ends? She was born in 1965 and never experienced race biology in practice. How is it, then, that this history nonetheless overwhelms her and fills her with a sense of shame? It is as if the hands of the scientists are still holding her body, fixing it, measuring it, violating it. 
Pirak Sikku never represents these violations directly; nor does she reproduce photographs or other material gathered by the race biologists. As she argues, that would only repeat the dehumanizing gesture that once victimized her people. Her works instead gesture towards these violations as one might point at a closed door behind which "physical examinations" and "treatments" are being conducted. In fact, her exhibitions and installations are informed by a taboo: the dehumanizing actions must not be displayed again, but nor must they be forgotten.

One voice in her works is allowed to break this taboo. This exceptional case is Elsa, an old woman and distant relative of Pirak Sikku's whose name stands in for all the nameless ones and whose testimonial represents numerous other stories never told. Elsa's voice is both subtle and straightforward:

It was at the primary school in Vakijaur that we children were photographed and measured. We stood in groups in front of the camera. It was a big camera that you went under a black cloth to look through. [...] we did not think all that much about it. We had to undress and that didn't feel very nice. I remember that it was cold and we were freezing. [...] We were ashamed of being Lapplanders. It was horrible (Pirak Sikku 2014b).

Pirak Sikku's account of the Sami people's encounter with racial biology consists mostly of constructed traces of this kind. In ”Muitobálgát”, or "Map of Memories”, which forms a kind of portal to her oeuvre, she draws a mind map or personal diagram that charts the process by which she has researched into the former State Institute of Racial Biology and its activities in her own native area of Jokkmokk (Pirak Sikku 2014b). Another of her works shows the contours of a body caught in a rigid and unnatural posture, as though locked up inside a body 
cage. Still another presents a blown-up page in a book by the racial biologist Sten Wahlund, Anthropometry of the Swedish Lapps (1941), into which Pirak Sikku has inserted her own anthropometric measurements.

”Having been an object, I want to become a subject and reappropriate my history”, writes Pirak Sikku (2014b). Many artists over the last decades have described their work in similar terms. Pirak Sikku thus inserts herself into an ongoing aesthetic and political programme in which the perspective shifts; in which we can follow how the marginalised rise up against dominant images of history and the contemporary situation that are fabricated by those at the centre.

According to Pirak Sikku, there are very few recorded instances of active Sami resistance against the treatment undertaken by the racial biologists. This of course gives particular weight to Elsa’s testimonial. However, Pirak Sikku also asks nature itself to bear witness. In many of her works, the landscape functions as a kind of shelter for those who had previously been violated by the racial biologists’ physical abuse. Through large-scale landscape painting and landscape photography, she also demonstrates that the treatment of the Sami by the Institute for Racial Biology is part of a broader history that concerns the continuing struggle over natural resources, grazing land, fishing waters and settlements. In this way, nature itself becomes a trace of a subaltern Sapmí resistance that seeks to reappropriate places once stolen by colonialism as landmarks in a landscape of belonging, of home.

To register this resistance, which was rarely recorded in official documents and seldom perceived as such by political and scientific authorities, one needs special antennas. Here it is appropriate to evoke John Scott's (1990) notion of a "hidden transcript” which structures the everyday life of subordinated and oppressed groups. This "transcript" or "secret program of resistance” is rarely attended to or recorded in the public sphere, and if such secret resistance does enter official discourse and politics, it typically does so in tight-lipped and harmless 
forms adapted to the languages and expectations of those in power. Only amongst the members themselves of the suppressed communities -- at home, around the table, at ceremonies and parties, in rumours and gossip -- will the "hidden transcript" attain more direct forms of expression. In situations of crisis it may also erupt in disobedience and insurrectionary behaviour.

As Pirak Sikku indicates, the relationship of the Sami to the racial scientists must be conceived as having been coded in such secretive ways. They allowed themselves to be measured, but they shook their heads in disbelief; they had their skull-measurements taken, but they exchanged ironic glances with their fellows across the room and tried to turn the situation to their own advantage. Herman Lundborg, chief scientist and director at the Institute of Racial Biology, remarks in one of his letters that he wished that "the Lapps were more cooperative”. Or as Elsa recalls: “I remember that my father thought it was a ridiculous survey, completely absurd.” As Pirak Sikku (2014b) also emphasises, communication between the Sami and the racial scientists was difficult if not impossible because they were separated by a linguistic abyss. She quotes one of the anonymous people who were subjected to the racial scientists: ”Gáhtjadit manen? Gåk? Ejma máhte dárosit.” (“You are asking why? How? But we didn’t know Swedish”.)

\section{Taking History Back}

Pia Arke’s work on Ittoqqortoormiit/Scoresbysund also revisits a scene of historical erasure. For our purposes, it should be stressed that Arke’s book Stories from Scoresbysund (2003/2010) is a fine example of postcolonial travel literature on the Arctic. It was not until I started to learn from her approach to Ittoqqortoormiit that I understood how the settlement could be aesthetically and journalistically decolonized. As I have already hinted at in my 
remarks on Arke’s postcolonial performances of “Arctic Hysteria”, this act of mental decolonization remains her greatest achievement and the central legacy of her work.

In Stories from Scoresbysund Arke sets herself the task of taking back her personal history. But to take back her history, she first has to discover how it came about that she was deprived of it, and this involves entering into close combat with world politics. Stories from Scoresbysund is therefore just as much a personal as a political book, but it is first and foremost a book filled with wonder, humour, and love for the people living in a remote spot on the fringes of the world, or rather a spot that Europeans placed on the world's fringes.

Yet Arke is also looking to take back history in another sense. She wants to take the history of her birthplace back to its unclear beginnings. It is worth recalling here that Scoresbysund was founded by the Danish state in 1924 and populated the following year with Greenlandic families who were lured or forcibly removed from Ammassalik, a thousand kilometres further south. Among them were Pia Arke’s maternal grandparents. Arke’s dream was to represent the founding of the settlement in a form that was loyal to their perspective.

This was a difficult and ambitious task, for Scoresbysund's story is not just about the approximately five hundred individuals who live there. Encapsulated in this story is the history of Danish colonialism with its headquarters in Copenhagen (Mikkelsen 1965). ${ }^{3}$ Also incorporated into it is the history of science: of ethnography, cartography, and the emergence of the so-called science of "eskimology”. Indeed, at its deepest level the story of Scoresbysund has to do with the entire history of Western imperialism, which set about dividing the world into a centre set in the European metropoles and an extensive periphery consisting of different, more or less sustainable colonial societies, like that of Scoresbysund.

My contribution to the book was to provide this backdrop of imperialism by showing how the powerful agents of exploration, territorial surveying, and cartography created the preconditions for the Scoresbysund settlement. The place called Ittoqqortoormiit today was a 
product of colonial masterplans conceived in Venice, Amsterdam, Edinburgh, London, Oslo, Brussels and Copenhagen from the seventeenth century onwards. The Danish plan was eventually victorious in the sense that it created "facts on the ground" of such permanence that the Danes could successfully beat their European competitors in the scramble for sovereignty over this particular part of the Arctic region.

Yet none of this would have been possible without the cooperation or enforced participation of East Greenlandic Inuit society. This, precisely, was Arke’s point. She was only too aware that she herself was living evidence of the ambiguous colonial liaison. The visual and literary narrative she offers in Stories from Scoresbysund thus constitutes an Arctic counterpart to the Afro-Caribbean project that Aimé Césaire (1939) once conceived of: his "Notebook of a Return to the Native Land" in which a half-forgotten and long-neglected place of origin was (re)discovered and valorized. Like Césaire, Arke found her origins to be without any cultural purity whatsoever. On the contrary, the Native Land was a scene of crimes and historical violations. Yet from these origins, and precisely because of their complex history of denial and evasion, it became possible to conceive of a history founded on the recognition of hybrid entanglements as the authentic mark of the postcolonial condition.

This is also evidenced in the empirical circumstances of Arke's book. The project originated in her bewildering return to her place of birth in summer 1997 and her newly gained acquaintance with her brother Ole Brønlund and his family, who lived in the settlement. When - as she wrote to me in a letter in autumn 1997 - she "returned home after 35 years”, she felt that this place, albeit charged with far-reaching historical processes, was marked by a deficit of historical awareness. There reigns, she wrote, "a state of historical embarrassment because no one really knows what the history [of the village] is.” This lack of historical awareness expressed itself evasively in the inhabitants' reluctance to speak of the first generation's trials and disappointments. Above all, it was negatively demonstrated in the 
fact that the community had no documentation of its own history. Instead the history of Scoresbysund was to be found outside Scoresbysund: history had "moved away and dispersed itself in picture archives, scientific studies, diaries, photo albums, attics and basement rooms in Denmark, Paris, New York, Oslo and Stockholm!” (Arke 1997)

Arke now wished to bring this wealth of documentation back to the place where it belonged. Consequently, one of the first things she did before her next trip in 1998 was to copy the photographs and documents she had found in European archives. Later, she exhibited this material in Scoresbysund's Town Hall. These photographic documents would form the basis of her book.

Arke's main aim was to challenge the colonial perspective on the basis of which this material had been collected and exhibited. If the documents presented the dominant view of history, she wanted to dissolve it by reinserting its enabling but marginalized supplement, the stories of the inhabitants themselves. The book thus offers a compelling picture from below of the geopolitics and the world-historical processes that created Scoresbysund. This includes Pia's account of her birth and childhood. To this adds the story of her mother along with a portrayal of her maternal grandparents, who had come to the great fjord with dreams of a new life. To these documents she then links a myriad of stories from Scoresbysund as told by siblings, cousins, neighbours and others in oral accounts or amateur photos. In this way, and step by step, Pia Arke seeks to emancipate herself and the inhabitants of Scoresbysund from the colonial narrative. In writing about her return to the native land, what was once the unacknowledged supplement now becomes the centre, the subject of a new narrative of East Greenland. It is a postcolonial narrative, to be sure, but also one that prefigures an Arctic yet to come. 


\section{Conclusion}

Katarina Pirak Sikku's signature image is a self-portrait in which she measures the height of her own skull with a caliper, an anthropometric tool used by the racial scientists. It looks as if her head is caught, squeezed, and compressed by the shiny instrument. Pirak Sikku’s mining of the archive of racial science translates into an effort to tear loose from the caliper. Where the scientists had previously seen a specimen of an inferior race, there is now a human being speaking back to them. Arke would create similar ironic images, posing as the exotic Eskimo, as the human object, dressed in or equipped with ethnographic paraphernalia (see Tupilakosaurus 2012).

As I have demonstrated in this article, it is not difficult to situate Pia Arke and Katarina Pirak Sikku among postcolonial artists who, over the past decades, have sought to reconquer histories and to restore life forms that have been oppressed, silenced, or ignored. However, such categories come with a risk. For does the classification as "Scandinavian Postcolonial" or "Postcolonial Arctic" not imply a marginalization of a new kind, especially when it is sanctioned by cultural institutions, publishing houses, and cultural critics with their roots in a Danish, Swedish, or western majority culture? Were we to attend more closely to Katarina Pirak Sikku’s and Pia Arke’s artistic practice, and were we to dare to dig deeper into the trauma of eugenics, race biology, and forced displacement, we would surely notice that their work is not just about the inherited shame and rage of the artists themselves; nor is it only about Sami and Inuit resistance. Rather, their work addresses the history of Sweden and Denmark, respectively. What emerges is an image of two Scandinavian colonial states which develop all conceivable methods - from land-grabbing and territorial conquest to psychiatry and racial science - in order to suppress indigenous groups and steal their resources. By making this past tangible, Arke and Pirak Sikku formulate a task that has just as much to do 
with the present: the task of decolonizing Sweden and Denmark and the national

historiographies that have served to justify both nations’ colonial cause.

In the foregoing I have discussed some of the narrative transformations, aesthetic inversions, and cultural subversions whereby creative artists, siding with indigenous communities once confined to being the mere setting or object of colonial travel writing, stake their claim as subjects of narrative performance and enunciation. This transformation is hardly surprising. Examples abound of similar processes in contemporary culture, not least in travel writing. What needs to be stressed is the aesthetic modality of performance that subtends these artists' subjectivation of the postcolonial text. It is crucially important to affirm these claims of authorship, not least because they entail a cultural emancipation of once subaltern communities.

My final conclusion, however, is slightly different. It makes little sense to delineate the contours of new narratives unless these are also seen as symbolic acts through which the colonial legacy of the dominant narrative is disclosed. In this sense, Arke and Pirak Sikku are not only inventing new narratives of the postcolonial Arctic. They also seem to be reinventing Scandinavian historiography, even rewriting the history of western dominance. But if this is true, it also amounts to saying that the question as to whether there is a new narrative of the postcolonial Arctic will continue to generate false answers as long as it is not also turned into a call for a new history of Europe itself.

\footnotetext{
${ }^{1}$ I would like to thank the organisers of and participants in the conference, "New Narratives of the Postcolonial Arctic”, held at Roskilde University in May 2015, where a preliminary version of this essay was given as a keynote address.

${ }^{2}$ First edition in Danish: Pia Arke and Stefan Jonsson, Scorsebysundhistorier: Fotografier, kolonisering og kortlaeggning (Copenhagen: Borgen, 2003); second trilingual edition (English, Greenlandic, Danish): Stories from Scoresbysund: Photography, Colonization, and Cartography (Copenhagen: Curatorial Action/Kuratorisk Aktion and the Pia Arke Society / Pia Arke Selskabet, 2010).

${ }^{3}$ Ejnar Mikkelsen (1965/1989), the founder of the Scoresbysund colony, has also written the most substantial Danish colonial account of the settlement's history.
} 


\section{References}

Arke, Pia. 2003. Scorsebysundhistorier: Fotografier, kolonisering og kortlaeggning.

Copenhagen: Borgen. With Stefan Jonsson.

Arke, Pia. 2010. Stories from Scoresbysund: Photography, Colonization, and Cartography.

Trilingual edition (English, Greenlandic, Danish). Copenhagen: Curatorial

Action/Kuratorisk Aktion and the Pia Arke Society/Pia Arke Selskabet. With

Stefan Jonsson

Arke, Pia. 1997. Letter to Stefan Jonsson, n.d.

Bravo, Michael and Sverker Sörlin, eds. 2002. Narrating the Arctic: A Cultural History of

Nordic Scientific Practices. Canton, Mass.: Science History Publications.

Césaire, Aimé. 1939/1994. Cahier d'un retour au pays natal, ed. Abiola Irele. Ibadan: New Horn Press.

Greimas, Algirdas Julien. 1966/1984. Structural Semantics: An Attempt at a Method. Lincoln: University of Nebraska Press.

Jameson, Fredric. 1974. The Prison-House of Language: A Critical Account of Structuralism and Russian Formalism. Princeton: Princeton University Press.

Jensen, Kaj Anders. 1996. ”Luk byen uden fremtid”, Nuuk n.d.

Jonsson, Stefan. "Disclosing the World Order: Decolonial Gestures in the Artistic Work of Pia Arke”. Third Text. Critical Perspectives on Contemporary Art \& Culture 27 (2): 242-259.

Jonsson, Stefan. 2005. “De stora husen i Ittoqqortoormiit”. Världen i vitögat: Tre essäer om västerländsk kultur. Stockholm: Norstedts.

Leane, Elizabeth, and Carolyn Philpott and Hanne Nielsen, 2014. "Scott at the Opera: interpreting Das Opfer (1937)”, The Polar Journal 4 (2): 354-376.

MacKenzie, Scott and Anna Westerstahl Stenport, eds. 2014. Films on Ice: Cinemas of the Arctic. Edinburgh: Edinburgh University Press.

Melville, Herman. 1851/2014. Moby Dick, or The Whale. Harmondsworth: Penguin.

Mikkelsen, Ejnar. 1965/1989. Scoresbysundkolonien, reprint of Tidsskriftet Grønland 1965:

"Scoresbysunds grundlæggelse fortalt af Ejnar Mikkelsen", Tidsskriftet Grønland 37 (7/8).

Pirak Sikku, Katarina. 2014a. Nammaláphán. Art exhibition at Bildmuseet, Umeå University.

Pirak Sikku, Katarina. 2014b. Elsa’s Story. Publication accompanying Nammaláphán. Art exhibition at Bildmuseet, Umeå University.

Propp, Vladimir. 1928/1968. Morphology of the Folktale, trans. Laurence Scott. Austin and London: University of Texas Press.

Ryall, Anka and Johan Schimanski and Henning Howlid Wærp, eds. 2010. Arctic Discourses. Newcastle-upon-Tyne: Cambridge Scholars Publishing.

Scott, John C. 1990. Domination and the Arts of Resistance: Hidden Transcripts. New Haven: Yale University Press.

Stuhl, Andrew. 2013. “The Politics of the 'New North': Putting History and Geography at stake in Arctic Futures”. The Polar Journal 3 (1): 94-119.

Tupilakosaurus Guide. 2010. Ed. Kuratorisk Aktion. Copenhagen: Pia Arke Selskabet and Kuratorisk Aktion, 2010.

Tupilakosaurus: An Incomplete(able) Survey of Pia Arke's Artistic Work and Research. 2012.

Ed. Kuratorisk Aktion. Copenhagen: Kuratorisk Aktion, 2012.

Wahlund, Sten. 1941. Anthropometry of the Swedish Lapps. Uppsala. 